\title{
Psychiatric Comorbidity in Droup Out from Educational Attainment Attending Tertiary Care Hospital
}

\author{
M S Islam ${ }^{1}$, S M A A Mamun ${ }^{2}$, A A Mamun Hossain ${ }^{3}$
}

\begin{abstract}
Background: Studies of the impact of mental disorders on educational attainment are rare. Mental disorders, those beginning in childhood or adolescence may increase the risk of early droup out from education. The latter has been shown to have adverse life-course consequences on individuals such as greater demand on social welfare entitlements.
\end{abstract}

Objective: To find out socio-demographic status and psychiatric comorbidity profile of patients with education droup out.

Design: Descriptive cross sectional study.

Setting: All cases were selected from patients attending at Comilla Medical College hospital and Tertiary Care hospitals in Comilla City from August 2014 to April 2015.

Methods: A total of $\mathbf{5 0}$ droup out patients aged $\mathbf{1 0}$ to $\mathbf{3 0}$ years who fullfiled the enrolment criteria included in the study. A semi structural questionnaire, DSM-5 and ICD-10 have been used as research instruments. The Frequency tables, summary tables and appropriate graphs were prepared to describe the population characteristics and study finding.

Result: Total 62 participants were approach for interview. Considering inclusion and exclusion criteria finally $\mathbf{5 0}$ patients were selected for the study. In this study, anxiety disorders was $\mathbf{8 \%}$, behaviourl impulse control disorders was $8 \%$, mood disorders was $16 \%$, substance use disorders was $24 \%$, schizophrenia spectrum disorders was $12 \%$ and composite psychiatric disorders was $32 \%$. Among droup out patient's non- completion of primary education was $14 \%$, non- completion of secondary education was $20 \%$, non- completion of higher secondary education was $24 \%$, not entry to tertiary education was $12 \%$ and non- completion of tertiary education was $30 \%$. Among behaviourlimpulse control disorders non- completion of primary education was $6 \%$, substance use disorders non- completion of higher secondary education was $10 \%$, mood disorder both non- completion of higher secondary education and noncompletion of tertiary education were $6 \%$. Among composite psychiatric disorders noncompletion of secondary education, non- completion of higher secondary education and noncompletion of tertiary education were $8 \%, 6 \%$ and $12 \%$ respectively. Socioeconomic status represented the homogenous result in this study. Most of the psychiatric morbidity was male (62\%) and age group of $18-24$ years (54\%).

Conclusion: Onset of mental disorder and subsequent droup out from education that was found in this study. Further multi-centered prospective and population-based studies should be desined to fint out the exact situation.

${ }_{1}^{1}$ Dr. Md. Shahedul Islam, Assistant Professor, Dept. of Psychiatry, Comilla Medical College, Comilla.

2 Dr. Sk. Md Abdullah Al Mamun, Registrar, Dept. of Medicine, Rajshahi Medical College Hospital, Rajshahi.

${ }^{3}$ Dr.Abdullah Al Mamun Hossain, Associate Professor, Dept. of Psychiatry, Rajshahi Medical College, Rajshahi.

Dr. Md. Shahedul Islam, Assistant Professor, Dept. of Psychiatry, Comilla Medical College, Comilla. Mobile: 01712261296, 01719516598, E-mail:

dr.shahedislam@gmail,com 
Key words: Droup out, defense mechanism, vulnerable temperament and personality, adative function, childhood adversities, educational attainment.

Limitation of the study: This study was done in a single setting and by the same interviewer. So, there may be a chance of biasness. This study did not represent the natural scenario of Bangladesh due to its selective and small sample size.

TAJ 2013; 26: 38-42

\section{Introduction}

Studies of mental disorders may underestimate the long-term adverse consequences of such disorders owing to a dominant focus on disability contemporaneous with the acute phases of disorder. Of particular concern is the impact of mental disorders on educational attainment, an important determinant of adult life chances in both high-income and low- and middle-income families. ${ }^{1}$

Early-onset mental disorders, those beginning in childhood or adolescence may increase the risk of early termination of education. The latter has been shown to have adverse life-course consequences on individuals, such as poor health, as well as societal consequences, such as greater demand on social welfare entitlements. Early termination of education also affects the standard of living, social mobility and upbringing of citizenship. Because of these connections between mental disorders and educational attainment, mental health should be a focus of concern in the discussion of policy on education and workforce development. ${ }^{2,5}$

Studies of mental disorders and subsequent educational attainment have been limited to the USA and New Zealand. The mental disorders and subsequent early termination of education affect at all levels from primary through tertiary education. $^{11}$

\section{Material and Methods}

This was a descriptive type of cross sectional study conducted in the Comilla Medical College Hospital and Private Chamber of Comilla City. Duration of study was 6 month. Of 50 educational droup out patients who fullfiled the enrolment criteria (normal intelligence, not diagnosed as epilepsy) included in the study. Data were collected between August 2014 to April 2015. The study was a national probability sample of 50 patients aged 10 to 30 years living in households or in hostel accommodation. All racial and ethnic groups were represented. Semi structural questionnaire, WMH CIDI, DSM-5 and ICD-10 were were used for assessing mental disorders and collecting detailed information about the risk factors, psychiatric comorbodities, impairment, consequences sociodemographic and diagnostic information, as well as an account of educational droup out during the interviews. Following categories of mental disorders were considered: anxiety disorders, mood disorders, behaviour or impulse control disorders, substance use disorders and schizophrenia spectram disorder. All collected data would be checked and verified thoroughly for consistency as well as for completeness. Finally appropriate statistical tests were done to see the trends of the data. Frequency tables, summary tables and appropriate graphs would be prepared to describe the population characteristics and study finding.

\section{Results}

Total 62 participants were approach for interview. Considering inclusion and exclusion criteria finally 50 patients were selected for the study. In this study, most of the psychiatric morbidity presents in male (62\%) and age group of 18-24 years (54\%). Age range was 9-30 years.

Figure-1: Broad category of psychiatric disorders among droup out patients
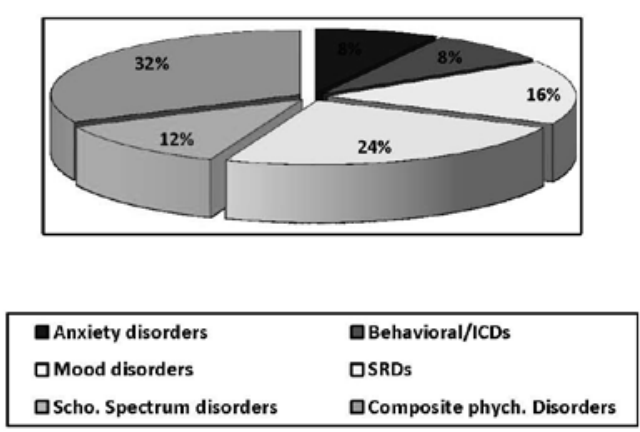
Table 1: Psychiatric disorders among droup out patients $(n=50)$

\begin{tabular}{|l|c|}
\hline Psychiatric disorders & n (\%) \\
\hline OCD & $2(4 \%)$ \\
\hline Adult or childhood separation anxiety & $1(2 \%)$ \\
\hline Adjustment disorder & $1(2 \%)$ \\
\hline Bipolar disorder & $4(8 \%)$ \\
\hline Any mood disorder & $4(8 \%)$ \\
\hline Conduct disorder & $1(2 \%)$ \\
\hline Oppositional defiant disorder & $2(4 \%)$ \\
\hline Any Impulse control disorder & $1(2 \%)$ \\
\hline Schizophrenia & $510 \%)$ \\
\hline Schizoaffective disorder & $1(2 \%)$ \\
\hline Cannabis use disorder & $3(6 \%)$ \\
\hline Alcohole use disorder & $4(8 \%)$ \\
\hline Yaba or CNS stimulant & $1(2 \%)$ \\
\hline Poly substance use disorder & $3(6 \%)$ \\
\hline Any substance use disorder & $1(2 \%)$ \\
\hline Composite psychiatric disorders & $16(32 \%)$ \\
\hline
\end{tabular}

Figure-2: Broad categorical distribution of droup out from educational attainment
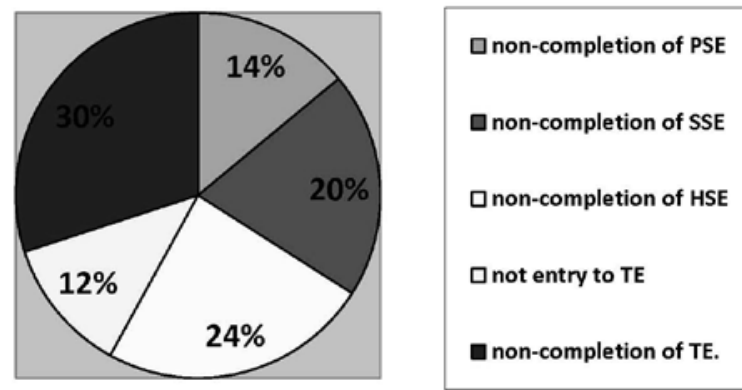

Table 2: Category of specific psychiatric disorder and educational droup out $(\mathrm{n}=50)$

\begin{tabular}{|l|l|c|}
\hline Disorders & Educational droup out & $\mathbf{n ~ ( \% )}$ \\
\hline \multirow{2}{*}{$\begin{array}{l}\text { Anxiety } \\
\text { disorders }\end{array}$} & non- completion of secondary education & $2(4 \%)$ \\
\cline { 2 - 3 } & non- completion of tertiary education & $2(4 \%)$ \\
\hline \multirow{4}{*}{$\begin{array}{l}\text { mood } \\
\text { disorders }\end{array}$} & non- completion of primary education & $1(2 \%)$ \\
\cline { 2 - 3 } & $\begin{array}{l}\text { non- completion of higher secondary } \\
\text { education }\end{array}$ & $3(6 \%)$ \\
\cline { 2 - 3 } & not entry to tertiary education & $1(2 \%)$ \\
\cline { 2 - 3 } $\begin{array}{l}\text { Behavior } \\
\text { or }\end{array}$ & non- completion of tertiary education & $3(6 \%)$ \\
\cline { 2 - 3 } ICDs & non- completion of primary education & $3(6 \%)$ \\
\hline \multirow{2}{*}{$\begin{array}{l}\text { substance } \\
\text { dise }\end{array}$} & non- completion of secondary education & $1(2 \%)$ \\
\cline { 2 - 3 } & non- completion of secondary education & $2(4 \%)$ \\
\cline { 2 - 3 } & $\begin{array}{l}\text { non- completion of higher secondary } \\
\text { education }\end{array}$ & $5(10 \%)$ \\
\cline { 2 - 3 } & not entry to tertiary education & $2(4 \%)$ \\
\cline { 2 - 3 } & non- completion of tertiary education & $2(4 \%)$ \\
\hline
\end{tabular}

\begin{tabular}{|l|l|c|}
\hline \multirow{2}{*}{$\begin{array}{l}\text { schizophre } \\
\text { nia }\end{array}$} & non- completion of secondary education & $1(2 \%)$ \\
\cline { 2 - 3 } $\begin{array}{l}\text { spectrum } \\
\text { disorders }\end{array}$ & $\begin{array}{l}\text { non- completion of higher secondary } \\
\text { education }\end{array}$ & $1(2 \%)$ \\
\cline { 2 - 3 } & not entry to tertiary education & $2(4 \%)$ \\
\cline { 2 - 3 } & non- completion of tertiary education & $2(4 \%)$ \\
\hline \multirow{2}{*}{$\begin{array}{l}\text { composite } \\
\text { psychiatric } \\
\text { disorders }\end{array}$} & non- completion of primary education & $2(4 \%)$ \\
\cline { 2 - 3 } & $\begin{array}{l}\text { non- completion of secondary education } \\
\text { education }\end{array}$ & $4(8 \%)$ \\
\cline { 2 - 3 } & not entry to tertiary education & $3(6 \%)$ \\
\cline { 2 - 3 } & non- completion of tertiary education & $6(12 \%)$ \\
\hline
\end{tabular}

Table 3: Distribution of respondents by sociodemo graphic characteristics $(n=50)$

\begin{tabular}{|c|c|c|}
\hline Characteristics & \multicolumn{2}{|c|}{ Respondents n (\%) } \\
\hline \multirow[t]{3}{*}{ Age (in years) } & $<18$ & $14(28 \%)$ \\
\hline & $18-24$ & 27 (54\%) \\
\hline & $>24-30$ & $9(18 \%)$ \\
\hline \multirow[t]{2}{*}{ Sex } & Male & $31(62 \%)$ \\
\hline & Female & $19(38 \%)$ \\
\hline \multirow[t]{3}{*}{ Religion } & Islam & $40(80 \%)$ \\
\hline & Hindu & $9(18 \%)$ \\
\hline & Buddis & $1(2 \%)$ \\
\hline \multirow[t]{4}{*}{ Educational status } & Below PSC & $7(14 \%)$ \\
\hline & PSC & $9(18 \%)$ \\
\hline & SSC & $16(32 \%)$ \\
\hline & HSC & $18(36 \%)$ \\
\hline \multirow[t]{5}{*}{ Occupation } & Unemployed & $25(50 \%)$ \\
\hline & Farmer & $5(10 \%)$ \\
\hline & House wife & $4(8 \%)$ \\
\hline & Business & $6(12 \%)$ \\
\hline & Others & $10(20 \%)$ \\
\hline \multirow[t]{3}{*}{ Marital statu } & Unmarried & $30(60 \%)$ \\
\hline & Married & $15(30 \%)$ \\
\hline & Divorce & $5(10 \%)$ \\
\hline \multirow[t]{2}{*}{ Famiy pattern } & Single & $40(80 \%)$ \\
\hline & Joint & $10(20 \%)$ \\
\hline \multirow[t]{3}{*}{ Habitat } & Rural & $29(58 \%)$ \\
\hline & Semiurban & $8(16 \%)$ \\
\hline & Urban & $13(26 \%)$ \\
\hline \multirow{3}{*}{$\begin{array}{l}\text { Socioeconomical } \\
\text { status }\end{array}$} & Low class & $18(36 \%)$ \\
\hline & Middle class & $26(52 \%)$ \\
\hline & High class & $6(12 \%)$ \\
\hline
\end{tabular}

\section{Discussion}

Educational droup out is not a disease, rather it is the result of a mental difficulties such as substance use disorders, behavior/impulse control disorders, mood disorders, anxiety disorders and schizophrenia spectram disorders. Based on some research evidence as well as consensus, common associated cause of educational droup out is often 
identified and the consequences become evident by educational difficulties and living skills. ${ }^{11.12}$

It was important to understand and focus probable mental disorders of educational droup out persons. Reviewing different literature on educational droup out, we tried to understand the distress of huge burden of psychiatric problem on persons with educational droup out. Considerable evidence indicates that substance use disorder and behavior/impulse control disorders are more frequent among droup out persons than other disorders. We observe psychiatric disorders among persons with educational droup out. Socioeconomic status represented the homogenous result in this study. This result is consistent with the previous study. ${ }^{11}$

We found different specific types of anxiety, mood, behaviour/impulse control disorders, substance use disorders and schizophrenia spectram disorders. Of 50 educational droup out patients OCD was 4\%, adult or childhood separation anxiety was $2 \%$, adjustment disorder was $2 \%$, bipolar mood disorder was $8 \%$, any mood disorder was $8 \%$, conduct disorder was $2 \%$, oppositional defiant disorder was $4 \%$, any impulse control disorder was $2 \%$, schizophrenia was $10 \%$, schizoaffective disorder was $2 \%$, cannabis use disorder was $6 \%$, alcohole use disorder was $8 \%$, yaba s or CNS stimulant was $2 \%$, poly substance use disorder was $6 \%$, any substance use disorder was $2 \%$ and composite psychiatric disordesr was $32 \%$. All of these have higher incidence among person with educational droup out. ${ }^{5}$

The present study showed that alcohole use disorder, cannabis use disorder, bipolar mood disorder and schizophrenia were more common disorders among persons with educational droup out. Among droup out patient's non- completion of primary education, non- completion of secondary education, non- completion of higher secondary education, not entry to tertiary education and non- completion of tertiary education were $14 \%, 20 \% 24 \%, 12 \%$ and $30 \%$ respectively. In case of anxiety and mood disorders, large number of patient inter to tertiary education. We found that the largest group of patients' droup out in composite psychiatric disorders, substance use disorders, schizophrenia, mood disorders and behavior/impulse control. These studies found significant associations between mental disorders and subsequent early droup out from education at all levels from primary through tertiary education. These finding also consistent with the previous study. ${ }^{5}$

In Bangladesh, generally substance use disorder and behavior/impulse control disorders are the commonest cause of educational droup out. We found that the largest group of patient's attent outpatient and inpatient department of tertiary level of this zone. This may be due to protective factors of Bangladesh thes may have reflected in the present study. The findings emphasize the necessity to evaluate psychiatric problems in persons with educational droup out. We suggest that assessment of the vulnerable temperament and personality, mood and emotional problem can make the persons proper function in future life. ${ }^{5}$

We recommended making awareness among family members, health workers, agencies who work for psychiatric disorders, pediatricians, neurologist, psychologist, social workers, school teachers, psychiatric nurses. They will work together as a multidisciplinary team for children, adolescents and adults on the management of psychiatric disorders. ${ }^{6,7,8}$

The findings emphasize the necessity to evaluate psychiatric problems in persons with educational droup out for early diagnosis and proper management to improve tha quality of life of those persons. Early diagnosis and referral to a psychiatrist or psychologist for treatment of the underlying psychopathology with individual and family therapy is the mainstay of successful management of educational droup out. ${ }^{10.11 .12,}$

\section{Conclusion}

Onset of mental disorder and subsequent droup out from education that was found in this study. Further multi-centered prospective and populationbased studies should be desined to fint out the exact situation. 


\section{References}

1. Kaplan HI \& Sadock BJ. Synopsis of psychiatrybehavioral science/clinical psychiatry.10 ${ }^{\text {th }}$ edition, Philadelphia: Lippincott Williams \& Wilkins, (2012).

2. American Psychiatric Association. Diagnostic and Statistical Manual of Mental Disorders ( $4^{\text {th }}$ edition) $\left(\mathrm{DSM}-5^{\mathrm{TM}}\right)$. APA, (2014).

3. Shamim Ferdous, Sultana S Zaman, Nyla Z Khan, Maureen Durkin, Abbey L Berg. Prevalence of Childhood Disability: The TQP Study in Bangladesh. Creating barrier free inclusive community and rights based society for children with disability. 2005: 16-25.

4. Rabbani MG, Alam MF, Shafiqul MS, Sarkar M. Prevalence of mental disorders, mental retardation, epilepsy and substance abuse in children. Ministry of Health and Family Welfare. Sponsored by WHO. 2009.

5. Lee S, Tsang A, Breslau J, et al. Mental disorders and termination of education in high- income and ILAMI-income countries: epidemiological study 2011; 194: 411-417.

6. Woodward LJ, Fergusson DM. Life course outcomes of young people with anxiety disorders in adolescence. J Am Acad Child Adol Psychiatry 2001; 40: 1086-93.

7. Fergusson, DM, Woodward LJ. Mental health, educational and social role outcomes of adolescents with depression. Arch Gen Psychiatry 2001; 59: 225-31.

8. United Nations Development Program. Human Development Report 2004: Cultural Liberty in Today's Diverse World. United Nations, 2004

9. Hishinuma ES, Else IRN, Chang JY, Goebert DA, Nishimura ST, Choi-Misailidis S, et al. Substance use as a robust correlate of school outcome measures for ethnically diverse adolescents of Asian/Pacific Islander ancestry. Sch Psychol Q 2006; 21: 286-322.

10. Kessler RC, Haro JM, Heeringa SG, Pennell BE, Ustun TB. The World Health Organization World Mental Health Survey Initiative. Epidemiol Psichiatr Soc 2006; 15: 161-6.

12. Efron B. Logistic regression, survival analysis, and the Kaplan-Meier curve. J Am Stat Assoc 1988; 83: 414-25. 